\title{
SIPOU (Siphonosoma australe-australe): PEMANFAATANNYA SEBAGAI BAHAN PANGAN
}

\author{
Sipou (Siphonosoma australe-australe): \\ The utilization of Sipou as a food material \\ Shalawatun Amaliah Fatimah*, Asnani, Suwarjoyowirayatno \\ Jurusan Teknologi Hasil Perikanan, Fakultas Perikanan dan IImu Kelautan Universitas Halu Oleo, Kendari, \\ Sulawesi Tenggara, Indonesia \\ *Email korespondensi: amaliah.fatimah.af@gmail.com (Telp: + +6281242481240) \\ Diterima: 30 Januari/ Disetujui 1 Maret 2021
}

Cara sitasi: Shalawatun Amaliah Fatimah, Asnani, Suwarjoyowirayatno. 2021. Sipou (Siphonosoma australe-australe): pemanfaatannya sebagai bahan pangan. Jurnal Fish Protech. 4(1):19-27.

\begin{abstract}
Sipou (Siphonosoma australe-australe) or sipuncula (peanut worm) is a marine animal that can be found in the coastal areas of Toronipa, Konawe Regency, Southeast Sulawesi. Sipou has been used as food and traditional medicine. It has been researched that it has a complete nutritional content, traditionally used as a nutraceutical ingredient against tuberculosis, regulates the function of the stomach and spleen, and restores health caused by pathogens. Due to its broad benefits, Sipou is now known to have an anti-inflammatory, anti-diabetic or antihyperglycemic function in what has been done on its extracts. Indonesia is a region that holds a wealth of various types of marine animals, one of which is sipou, which until now is still very rarely used, even the processing technology is new in the form of dry raw materials and used as food ingredients. Meanwhile, sipou research as a medicinal ingredient is still limited and Sipou products are still exported as dry whole raw materials to Asian countries. Given its potential resources, research towards industry, processing, pharmaceuticals and health needs to be increased. The research is intended to further introduce and support various industries in increasing the added value of processing and processed Sipou which is very useful.
\end{abstract}

Keywords: Foodstuffs, Sipou, processing techniques

\section{ABSTRAK}

Sipou (Siphonosoma australe-australe) atau sipuncula (peanut worm) merupakan hewan laut yang dapat ditemui di wilayah pesisir pantai Toronipa, Kabupaten Konawe, Sulawesi Tenggara. Sipou telah dimanfaatkan sebagai bahan pangan dan pengobatan tradisional. Telah diteliti memiliki kandungan nutrisi yang lengkap, secara tradisional telah dimanfaatkan sebagai bahan nutraceutical terhadap penyakit tuberkulosis, pengatur fungsi lambung dan limpa, serta pemulihan kesehatan yang disebabkan oleh patogen. Karena manfaatnya yang cukup luas, kini sipou diketahui memiliki fungsi sebagai antiinflamasi, anti diabetes atau antihiperglikemik dalam penetian yang telah dilakukan terhadap ektraknya. Indonesia merupakan wilayah yang menyimpan kekayaan berbagai jenis hewan laut, salah satunya adalah sipou yang hingga saat ini pemanfaatannya masih sangat jarang bahkan teknologi pengolahannya baru dalam bentuk bahan baku kering dan dimanfaatkan sebagai bahan pangan. Sementara penelitian sipou sebagai bahan obat masih terbatas dan produk sipou masih diekspor dalam bentuk bahan baku utuh kering ke negara-negara Asia. Mengingat sumberdayanya yang cukup potensial, maka penelitian ke arah bidang industri, pengolahan, farmasi dan kesehatan perlu ditingkatkan. Penelitian tersebut untuk lebih memperkenalkan dan mendukung berbagai industri dalam peningkatan nilai tambah dari pengolahan dan hasil olahan sipou yang sangat bermanfaat.

Kata kunci: Bahan pangan, Sipou, teknik pengolahan 


\section{PENDAHULUAN}

Sipuncula atau yang dikenal sebagai cacing kacang atau peanut worm karena dapat memasukkan sebagian dari tubuhnya hingga membentuk seperti kacang, termasuk biota laut yang berbadan lunak yang berbentuk memanjang seperti selom (coelomate) yaitu rongga yang berisi cairan. Hewan ini termasuk dalam kelas Sipunculidea dari bangsa Animalia yang merupakan hewan seperti annelida namun tak bersegmentasi (unsegmented) dan bertubuh lunak (soft-bodied), halus atau tanpa sisik, chaetae maupun duri. Sipuncula tersebar diberbagai perairan, salah satunya di pesisir Pantai Toronipa, Desa Tronipa, Kecamatan Toronipa, Kabupaten Konawe, Provinsi Sulawesi Tenggara, yang dikenal dengan nama lokal Sipou dari spesies (Siphonosoma australe-australe) (Nurhikma et al., 2017).

Sipou berasal dari Filum Sipuncula yang merupakan biota laut dengan status atau tanda pengenal yang kontrovertif, dari penampilan luarnya, hewan ini mirip dengan cacing, sehingga kehadirannya pada ekosistem pesisir memang relatif kurang dikenal jika dibandingkan dengan cacing laut jenis lainnya (Suwajoyowirayatno et al., 2019), namun jenis ini telah dikenal diberbagai literature sebagai cacing tanpa segmen (unsegmented marine worm). Secara visual, sipou berwarna coklat muda (kream) hingga putih. Tubuh yang terdiri dari otot badan (muscular truk) dan sebuah tempat anterior, bagian introvert yang lebih kecil (Edmonds, 2000), tubuh yang lunak mengharuskan sipou untuk mempertahankan diri dengan menggulung atau memperkecil tubuhnya, sipou sendiri tidak memiliki racun untuk dikeluarkan dan memanfaatkan detritus organik yang terdapat diair atau substrat (Aninda, 2016) sebagai makanan, sehingga dimanfaatkan oleh masyarakat sebagai bahan pangan, dengan penanganan yang lebih mudah karena tidak ada pengolahan khusus untuk menghilangkan kandungan berbahaya.
Pemanfaatan sipou oleh masyarakat sekitas daerah pesisir sebagai bahan penyumbang nutrisi protein bagi tubuh karena dipergunakan sebagai pendamping karbohidrat atau bahan pangan berupa lauk sehari-hari. Masyarakat pesisir Kendari juga memiliki kepercayaan mengkonsumsi cacing laut sebagai obat tradisional, karena beberapa senyawa kimia yang ada pada cacing laut diduga memiliki khasiat tersebut (Nurhikma et al., 2017). Kegunaan lainnya sebagai umpan untuk menangkap ikan bagi para nelayan.

Sebagian besar masyarakat Indonesia telah mengonsumsi sipuncula dengan berbagai jenis dan spesies, seperti pada wilayah Maluku Tengah (Silaban, 2019), wilayah Raja Ampat dan Manokowari yaitu kelompok sipuncula khususnya spesies Sipunculus nudus sebagai bahan makanan (Leiwakabessy, 2017) dan pada daerah Bangka-Belitung yaitu cacing kacang dengan sebutan kekuak atau wak-wak (Fakhrurrozi et al., 2009) telah dimanfaatkan sejak lama.

Selama ini sebagaian besar sipou/sipuncula di Indonesia diolah menjadi bahan baku kering dan diekspor ke berbagai negara. Sementara penggunaannya secara lokal telah banyak dimanfaatkan untuk bahan konsumsi, namun informasi mengenai kelompok spesies ini masih sangat sedikit, maka seharusnya dilakukan berbagai kajian dan penelitian untuk membangun informasi-informasi yang komunikatif dan bermanfaat ilmu pengetahuan khususnya pada hasil-hasil perikanan Indonesia. Oleh karena itu, upaya memperkenalkan sipou sebagai bahan pangan untuk berbagai keperluan dapat memberikan informasi kepada berbagai pihak.

\section{DEFINISI DAN GAMBARAN UMUM}

Sipuncula berasal dari kerajaan Animalia yang dikenal pada kelas Sipinculidea dan termaksud ke dalam genus Siphonosoma (Cutler, 1994) yang teridentifikasi sebanyak 367 spesies dan subspesies, tediri dari 13 genus, 4 famili, dan 
1 kelas, yang dalam proses evolusi perbedaan menonjol dari bagian utama Protostomia yang mengarah ke Annelida dan Mollusca (Murina, 1984). Penggambaran klasifikasi mencirikan bentuk yang khas dari kelompok ini.

Sekelompok invertebrata laut yang bertubuh lunak, tidak tersegmentasi, coelomate, seperti cacing. Tubuh terdiri dari batang berotot dan ditempatkan di anterior, dengan bagian introvert lebih ramping. Daerah mulut berada pada bagian ekstremitas anterior introvert dan saluran pencernaan yang panjang, berulang secara spiral terletak di dalam rongga tubuh yang luas atau coelom. Anus terletak di punggung, biasanya di permukaan anterior tubuh dekat pangkal introvert. Tentakel mengelilingi, atau terhubung dengan mulut dengan dua nephridia, kadang-kadang hanya satu. Sistem saraf, meskipun tidak tersegmentasi, adalah seperti annelidan, terdiri dari kabel saraf ventral yang panjang dan otak yang ditempatkan di anterior. Jenis kelaminnya terpisah, pembuahan bersifat eksternal dan pembelahan zigot adalah spiral. Larva adalah trochophore yang berenang bebas, dan hidup di liang pasir, bebatuan, sela-sela batu dan tempattempat yang terlindungi (Edmonds, 2000).

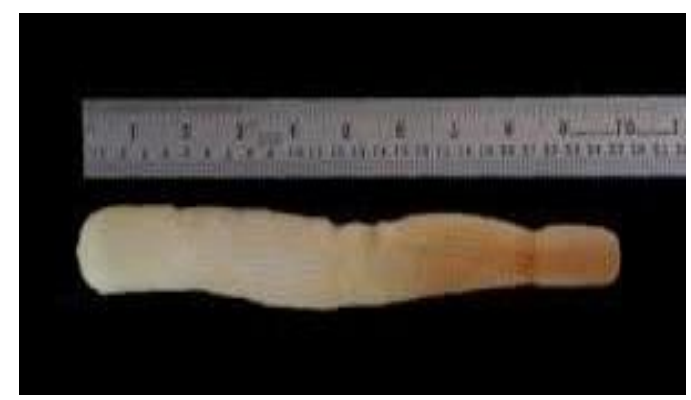

Gambar 1. Siphonososma australe-australe (Sumber: Nurhikma et al., 2017)

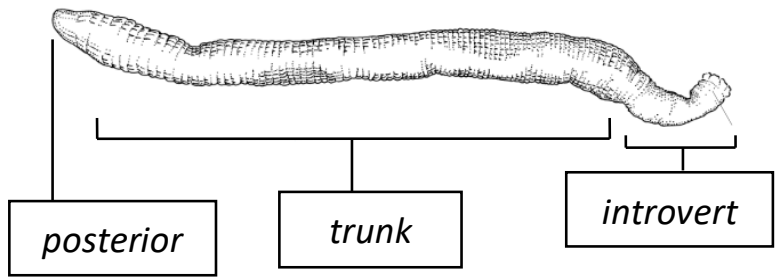

Gambar 2. Pembagian Tubuh Siphonosoma australe-australe
Sipuncula secara morfologi terdiri dari strutur tubuh berupa batang tubuh yang biasanya kokoh dan silindris, panjang dan seperti cacing, bundar, berbentuk buah pir, seperti labu atau dipuntir menjadi spiral, dan lebih besar dari bagian introvertnya. Dinding tubuh biasanya terdiri dari bagian yang tebal dan sangat berotot. Bagian Introvert muncul pada atau dekat anterior ekstremitas bagian tubuh dan diameternya terasa lebih kecil daripada batang tubuh. Ini adalah organ yang sangat elastis yang mampu berekstensi dengan cukup dan, dalam waktu tertentu dapat teretraksi total atau sebagian dalam rongga tubuh. Papilla dan kelenjar badan dan sensorik biasanya ada pada permukaan batang dan introvert; terkadang mereka menonjol. Pengait dan/atau duri yang sering ditemukan di permukaan introvert membantu pengumpulan makanan. Sejumlah tentakel dikaitkan dengan mulut dan terlibat dalam pertukaran gas pernapasan dan pengumpulan partikel makanan. Batangnya melingkupi coelom besar berisi cairan . Saluran pencernaan yang sangat panjang terletak kurang lebih bebas dalam cairan coelomic; terdiri dari: kerongkongan, yang melekat sebagian besar oleh mesenteries ke otot retraktor; loop usus yang turun dan naik secara spiral, dan; dubur lurus pendek. Kerongkongan terdiri dari pembuluh kontraktil tubular ('polian' atau 'kompensasi') yang berisi cairan dan sel darah (Edmonds, 2000).

\section{KANDUNGAN NUTRISI SIPOU}

Cacing laut memiliki kandungan gizi yang cukup lengkap sehingga dapat dimanfaatkan sebagai bahan makanan fungsional. Kandungan gizi yang terdapat pada cacing laut yakni protein, lemak, karbohidrat, abu, asam lemak dan asam amino, vitamin A, B1, B6, B12, E, dan mineral P, 12, $\mathrm{Ca}, \mathrm{Mg}, \mathrm{C}$ yang hampir setara dengan kandungan gizi padaikan (Silaban 2012). Penelitian potensi cacing laut sebagai bahan alami dilakukan oleh Silaban (2019) terhadap cacing laut sia-sia (Sipuncula sp.) dari Perairan 
Nalahia yang menyatakan bahwa cacing tersebut memiliki kandungan protein tertinggi sebesar 16,88-17,13\%.

Protein, kabohidrat dan lemak merupakan bahan organik yang terendapkan dalam sedimen (Fauzan, 2009 dalam Siregar, 2011) yang dimanfaatkan oleh sipou sebagai bahan makanan. Selain itu organisme yang hidup atau tinggal dalam ekosistem lamun memiliki kandungan gizi yang cukup tinggi karena lamun memiliki kandungan gizi seperti protein, karbohidrat, lemak dan serat. Kandungan gizi pada sipou telah dilakukan dilakukan penelitian mengenai komposisi kimia cacing laut meliputi kandungan asam amino, asam lemak, dan kandungan mineral cacing laut yang berasal dari Perairan Toronipa Provinsi Sulawesi Tenggara (Nurhikma et al., 2017).

Kadar protein menjadi bahan pertimbangan dalam pengaplikasiaan sebagai bahan pangan, protein terdapat pada sebagian besar permukaan tubuh (trunk) lunak dan kenyal yang terdiri dari sistem syaraf dan otot-otot. Struktur kutikula khusus (pelindung posterior atau papila tubuh) dikenal dengan cuticle yang terdapat pada dinding tubuh utama (trunk) berupa dermis yang terdiri dari serat kolagen (Edmonds, 2000).

Tabel 1. Komposisi Kimia Siphonosoma australe-australe dari Perairan Laut Sulawesi Tenggara

\begin{tabular}{lll}
\hline Kandungan & Segar & Freezed \\
\hline Air $(\%)$ & $85,25 \pm 0,42$ & 13,69 \\
Abu (\%) & $3,03 \pm 0,19$ & 15,08 \\
Protein (\%) & $10,11 \pm 0,80$ & 56,35 \\
Lemak (\%) & $0,54 \pm 0,29$ & 9,82 \\
Karbohidrat* $^{*}(\%)$ & $1,07 \pm 1,23$ & 5,06 \\
\hline
\end{tabular}

Keterangan : *by difference

Sumber : Nurhikma et al. (2017)

Siphonosoma australe memiliki kandungan gizi yang hampir lengkap (Nurhikmah et al., 2017). Kandungan nutrisi berbeda menurut lokasi tetapi memiliki komposisi yang lengkap dan menyerupai ikan yang terdiri dari kadar air 74,96-79,12\%, kadar abu 2,41-3,06\%, karbohidrat 1,03-3,86\%, protein $16,88-17,23 \%$ serta lemak $0,22-0,28 \%$, asam amino, asam lemak, vitamin $A, B 1, B 6, B 12$, E dan mineral Fosfor 0,98-1,09\%, lodium 5,936,65\%, dengan kandungan Calsium 6,16-12,42\% yang lebih tinggi dari mineral lainnya (Silaban, 2012).

Proses pengeringan dapat menyebabkan kandungan air pada sipou menjadi berkurang atau sedikit, sehingga memaksimalkan kandungan lainnya seperti protein yang merupakan kandungan unggulan dari sipou.

Tabel 2. Perbandingan Komposisi Kimia Sipou

\begin{tabular}{lll}
\hline Kandungan & Segarc $^{c}$ & Kering $^{c}$ \\
\hline Air $(\%)$ & 79,59 & 12,39 \\
Abu $(\%)$ & 0,64 & 8,02 \\
Protein $(\%)$ & 17,39 & 54,08 \\
Lemak $(\%)^{\text {Karbohidrat }}{ }^{*}(\%)$ & 1,28 & 2,46 \\
Serat Kasar (\%) & - & - \\
\hline
\end{tabular}

Keterangan : *by difference

Sumber : Rahayu (2018)

Kandungan asam amino yang terdapat pada sipou terdiri dari 2 jenis asam, yaitu asam amino esensial dan asam amino non esensial yang terdiri dari 15 sub indikator asam amino.

Tabel 3. Kandungan Asam Amino Esensial Siphonosoma australe dari Perairan Toronipa, Kab. Konawe, Sultra. 
Asam amino esensial yang terkandung pada Siphonosoma australe dapat dilihat pada Tabel 3 yang terdiri dari sembilan jenis asam amino. Asam amino esensial tertinggi terdapat pada arginin yaitu 3,04\% pada kondisi segar sedangkan pada kondisi freeze dry yaitu 5,52\% (Nurhikma et al., 2017).

Tabel 4. Kandungan Asam Amino Non Esensial Siphonosoma australe dari Perairan Toronipa, Kabupaten Konawe, Sulawesi Tenggara

\begin{tabular}{lll}
\hline Asam amino & $\begin{array}{l}\text { Segar } \\
(\% \mathrm{~b} / \mathrm{b})\end{array}$ & $\begin{array}{l}\text { Freeze } \\
(\% \mathrm{ob} / \mathrm{b})\end{array}$ \\
\hline Asam aspartat & 3,08 & 3,90 \\
Asam glutamat & 6,53 & 8,53 \\
Serina & 1,26 & 1,60 \\
Glisina & 3,29 & 6,32 \\
Alanina & 2,38 & 4,10 \\
Tirosina & 0,97 & 1,02 \\
\hline Total & 17,51 & 25,47 \\
\hline
\end{tabular}

Sumber : Nurhikma et al. (2017)

Kandungan asam amino non esensial yang terkandung pada Siphonosoma australe-australe yang ditemui di kawasan perairan Toronipa, Sulawesi Tenggara dapat dilihat pada Tabel 4 terdiri dari enam jenis asam amino. Asam amino non-esensial yang tertinggi terdapat pada asam glutamat yaitu $6,53 \%$ pada kondisi segar dan freeze dry yaitu $8,53 \%$. Hasil pengujian asam amino arginin dan asam glutamat merupakan asam amino yang paling banyak terkandung dan dapat digunakan sebagai antiinflamasi (Nurhikma et al., 2017).

Skor kimia merupakan skor terhadap kualitas protein dari asam amino yang dibandingkan dengan profil asam amino yang terdapat pada protein standar. Profil asam amino berdasarkan skor kimia terendah adalah asam amino histidin yang berfungsi sebagai asam amino pembatas. Skor kimia asam amino $S$. australe segar yakni $24,67 \mathrm{mg} / \mathrm{g}$ protein dan hasil freeze $d r y$ sebesar $20,67 \mathrm{mg} / \mathrm{g}$ protein. Skor asam amino merupakan nilai terkecil berdasarkan tingkat kecukupan asam amino yang biasanya disebut dengan TAKE (Nurhikma et al., 2017).

S. australe pada pengujian asam lemak mengandung 12 asam lemak jenuh (saturated fatty acid/SFA), 5 asam lemak tak jenuh tunggal (monosaturated fatty acid/MUFA), dan 13 asam lemak tak jenuh majemuk (polysaturated fatty acid/PUFA). Hasil analisis kandungan asam lemak ditunjukkan pada asam lemak SFA tertinggi yakni asam palmitat sebesar $1,96 \%$ pada kondisi segar dan 2,64 pada kondisi freeze dry. Kandungan MUFA tertinggi $S$. australe segar yakni asam palmitoleat yaitu $0,31 \%$ dan freeze $d r y$ yaitu $0,27 \%$. Kandungan PUFA tertinggi yakni asam arakidonat segar sebesar $2,80 \%$ dan asam oleat yaitu $1,97 \%$ freeze dry (Nurhikma et al., 2017).

Kandungan mineral dari $S$. australe terdiri dari kalsium (Ca), kalium (K), magnesium $(\mathrm{Mg})$, natrium $(\mathrm{Na})$ dan kandungan logam terdiri dari lead $(\mathrm{Pb})$, kadmium $(\mathrm{Cd})$, fosfor $(\mathrm{P})$. Hasil analisis kandungan mineral menunjukkan bahwa natrium merupakan mineral tertinggi pada kondisi segar atau basah $(43.700 \mathrm{mg} / \mathrm{kg})$ dan pada kondisi kering dari hasil freeze dry $(127.334 \mathrm{mg} / \mathrm{kg})$, kandungan mineral terendah terdapat pada kalium $(1.600 \mathrm{mg} / \mathrm{kg})$ pada kondisi basah dan pada kondisi kering $(4.508 \mathrm{mg} / \mathrm{kg}$ ) (Nurhikma et al., 2017).

Jenis Sipunculus nudus memiliki kandungan protein yang besar yaitu hingga $81,64 \pm 1,22 \%$, kadar lemak 1,52 $\pm 0,51 \%$, kadar air 7,62 \pm $0,51 \%$, karbohidrat $7,03 \pm 0,77 \%$, serat kasar $0,98 \pm 0,081 \%$. Jenis lain dari Sipuncula yang telah terkonfirmasi berdasarkan penelitian Fakhrurrozi (2011) mengemukakan komposisi kimia jenis Xenosiphon sp yang terdapat di Kepulauan Bangka-Belitung memiliki kandungan gizi yang tinggi. 


\section{SIPUNCULA SEBAGAI BAHAN NUTRACEUTICAL}

Kandungan protein dapat juga berfungsi untuk memperkuat sistem daya tahan tubuh serta menghasilkan hormon dan enzim untuk melancarkan metabolisme (Lehninger, 1994). Telah dikonfirmasi dalam penelitian bahwa Sipuncula telah lama digunakan sebagai obat tradisional Cina untuk pengobatan penyakit tuberkulosis, pengatur fungsi lambung dan limpa, serta pemulihan kesehatan yang disebabkan oleh pathogen (Zang dan Zi, 2011).

Masyarakat lokal Indonesia menyebutkan bahwa mengonsumsi makanan Honingka (Siphonosoma australe-australe) beberapa kali lebih sering dapat memiliki dampak kesehatan seperti kekebalan daya tahan tubuh atau tidak gampang terserang oleh penyakit sehingga lebih kebal terhadap penyakit yang sering timbul pada musim khusu, hal ini disampaikan pada petikan wawancara oleh masyarakat daerah Wakatobi, Sulawesi Tenggara dalam penelitian kandungan nutrisi cacing honingka sebagai bahan pangan pada masyarakat pesisir (Rahayu, 2018).

Bagian yang penting dari sipou dengan kandungan serat kolagen tinggi adalah lapisan permukaan tubuh berupa dinding tubuh. Serat kolagen yang terkandung pada bagian tubuh dari sipou diekstraksi dengan tujuan untuk menghidrolisis rantai triple helix menjadi rantai panjang $\alpha$ helix dalam pemanfaatan sipou sebagai alternatif bahan baku pembuatan gelatin (Suwarjoyowirayatno et al., 2019). Penggunaan gelatin sebagai bahan dalam obat-obatan telah dikembangkan sejak lama ditemukan pada produk pharmaceutical seperti dalam formulasi hard capsules, soft capsule, tablet, tablet coating, miroenkapsulasi, suppositories, gelatin emulsions, absorbable gelatin sponge, plasma substitutes, absorbable gelatin film, plastilles and troches, dan bacterial growth media (GMIA, 2019). Gelatin sendiri memiliki manfaat fungsional dalam berbagai peruntukan, baik sebagai bahan pangan berupa nutrisi maupun kesehatan.

Ekstrak Sipunculus nudus dengan dosis 50 $\mathrm{mg} / \mathrm{kgBB}$ memiliki aktivitas antiinflamasi yang baik (Zhang et al., 2011). Data penelitian terkait pada spesies yang sama pada ekstrak etanol $S$. australe memiliki manfaat kesehatan sebagai antidiabetes atau antihiperglikemik terbaik pada dosis $45 \mathrm{mg} / \mathrm{kgBB}$ dengan aktivitas bioaktif senyawa flavonoid, alkaloid, saponin dan steroid (Aninda et al., 2016).

Berdasarkan penelitian yang telah dilakukan Purwaningsih (2014) menyatakan bahwa ekstrak etanol cacing laut memiliki potensi sebagai antidiabates melalui uji in vitro yang dapat menghambat aktivitas enzim a-glukosidase sebesar 16-24 ppm. Sehingga mengonsumsi marine worm sebagai bahan pangan dapat membantu dalam hal kesehatan dan dapat menjadi pilihan variasi makanan yang aman untuk dikonsumsi, serta tidak menuimbulkan kekhawatiran akan dampak kesehatan.

\section{JENIS DAN PERANAN SIPUNCULA SEBAGAI PANGAN}

Kepopuleran dan pemanfaatan sejauh ini hanya pada beberapa Sipuncula jenis tertentu yang dikonsumsi sebagai bahan makanan dan dikenal secara komersial oleh kalangan masyarakat pesisir. Pangan yang berasal dari sipuncula terdiri dari berbagai macam jenis, namun hanya dengan cara pematangan yang berbeda dan sebagian kecil tidak merubah bentuk maupun tekstur tubuh dari bahan baku awal. Beberapa hanya diperkecil ukurannya untuk mempermudah proses konsumsi. Fungsi sebagai bahan pangan sendiri telah dikenal luas bahkan hingga diberbagai wilayah penyebarannya.

Jenis Siphonosoma australe-australe dikonsumsi dengan berbagai metode yang umumnya dilakukan dalam beragam aktivitas perlakuan pemasakan, baik dengan pengolahan dengan merebus untuk proses pematangan 
maupun langsung dikonsumsi mentah tanpa proses pematangan terlebih dahulu sebagai bahan makanan/lauk, seperti halnya berlangsung pada daerah Sulawesi Tenggara yang menyebut dengan nama lokal yang khas, yaitu Sipou (Aninda et al., 2016).

Jenis yang sama juga telah dikonsumsi sebagai pendamping karbohidrat dalam bentuk lauk oleh masyarakat lokal dan dikomersilkan pada pasaran tradisional, seperti pada hasil wawancara menjelaskan bahwa oleh masyarakat diproses dan produksi sebagai variasi makanan atau makanan pendamping selain ikan yang mengandung manfaat lebih, seperti dipercaya memiliki manfaat bagi kesehatan. Sebagaimana petikan wawancara dalam sitasi dengan salah satu masyarakat setempat menyebutkan bahwa mengonsumsi jenis ini sebagai lauk, dalam kondisi mentah atau terlebih dahulu dikeringkan, dan beberapa dimatangkan dengan memasak dan menumisnya terlebih dahulu. Hal ini disampaikan oleh masyarakat Wakatobi sebagai wilayah bagian Sulawesi Tenggara yang menyebutkan dalam bahasa daerah setempat dengan nama Honingka (Rahayu, 2018).

Jenis Siphuncula sp. atau cacing kacang menjadi bahan pangan yang bernilai ekonomis setelah penelitian dilakukan dan mengarah pada hasil analisis perkembangan dalam agroindustri yang dilaksanakan pada produksi pengolahan rumah tangga sebagai bahan makanan yang berpotensi dalam permintaan ekspor yang cukup tinggi. Bahan baku cacing kacang segar dikeringkan untuk dikomersialkan dengan nilai tambah yang mencapai bobot Rp.117.495/kg terhitung dapat menguntungkan bagi pengolah cacing kacang. Salah satu potensi sumber daya perikanan jenis ini telah dilakukan dan dikembangkan oleh masyarakat sekitar daerah Desa Lemoea, Kulisusu, Buton Utara, Sulawesi Tenggar yang awalnya menjadikan cacing kacang sebagai bahan konsumsi sehari-hari dalam penyajian lauk pauk dan kemudian ditangkap lebih banyak untuk dijual oleh nelayan kepada pengepul industri kecil sehingga diolah dalam bentuk bahan baku kering (Akbar et al., 2019).

Kelompok sipuncula atau cacing kacang yaitu jenis Xenosiphon sp. (Fahkrurrozi, 2011) yang dikenal dengan nama lokal kekuak atau wak-wak merupakan jenis biota laut yang dimanfaatkan secara tradisional sebagai bahan pangan oleh nelayan dan masyarakat. Kekuak dikenal sebagai bahan panganan yang telah diperdagangkan berupa kekuak kering mentah di pasar tradisional, dan kekuak kering goreng (keripik) di toko makanan atau oleh-oleh khas setempat, meskipun begitu bisa juga dinikmati dari olahan segar atau olahan basahnya (digoreng, disop, dipanggang dan sebagainya), berbangai jenis pangan ini telah dikenal luas di Kepulauan Bangka-Belitung khususnya di Pangkalpinang, Sebagian lainnya jenis ini sengaja ditangkap sebagai produk pangan yang ditawarkan kepada etnis Tionghoa setempat (Fahkrurrozi et al., 2009).

Sipunculus nudus yang masih tergabung dalam keluarga Sipunculidae juga difungsikan sebagai bahan pangan (Pamungkas, 2010). Masyarakat pesisir telah memanfaatkan organisme Sipunculus nudus sebagai bahan pangan, yang mempunyai nilai kandungan gizi yang baik sebagai bahan makanan, karena memiliki kadar protein yang tinggi, telah diteliti dan menggambarkan bahwa tidak ada ukuran tertentu yang mengkhhususkan dalam mengonsumsi jenis ini, tetapi cacing dengan ukuran yang lebih besar menghasilakn persentase proksimat yang lebih besar. Sipunculus nudus yang dikonsumsi dan diteliti berasal dari perairan raja Ampat dan Manokowari, Papua Barat yang sejak lama telah dijadikan sebagai salah satu bahan makanan.

Berdasarkan studi etnoteknologi dan pemanfaatan Sia-sia (Sipunculus nudus) yang dikenal sebagai bahan pangan sejak lama oleh masyarakat tanpa musim tangkapan khusus. Secara turun-temurun sia-sia sudah dipakai oleh masyarakat sebagai umpan dan pangan sehari- 
hari. Bagi masyarakat, sia-sia menjadi salah satu pangan laut yang cukup digemari karena rasanya yang lezat. Berdasarkan kenyataan di lapangan, sia-sia menjadi salah satu biota laut yang cukup memberikan sumbangan yang besar bagi kehidupan masyakat Pulau Nusalaut, Maluku Tengah juga pada pulau Ambon dan Banda. Prosedur konsumsi dilakukan dengan memasak tetapi kebiasaan masyarakat mengkonsumsi segar dalam keadaan mentah. Kandungan nutrisi sia-sia tergolong bergizi tinggi karena memiliki komposisi nutrisi yang lengkap berupa protein, karbohidrat, lemak dan mineral (Silaban, 2019).

\section{TEKNIK PENGOLAHAN SIPUNCULA}

Potensi pengembangan agroindustri cacing kacang telah menjadi salah satu industri yang dapat dikembangkan di Desa Lemoea Kecamatan Kulisusu, Kabupaten Buton Utara. Cacing kacang dibeli dari masyarakat Desa Lemoea, Kemudian cacing kacang diolah dengan cara dikeringkan oleh oven khusus yang masih sangat tradisional, namun dengan masalah pokok yaitu tingkat pengetahuan dan keterampilan nelayan yang masih relatif rendah, kepemilikan modal usaha relatif terbatas, kegiatan produksi secara perseorangan yang tidak berkelompok, dan dengan akses teknologi yang terbatas. menjual atau menimbang cacing kacang ke industri rumah tangga yang berada di Desa Lemoea tersebut dengan harga lima belas ribu perkilo, industri rumah tangga tersebut mengolah cacing kacang basah menjadi kering dan di kemas lalu di pasarkan atau di ekspor lokal ke Internasional ke salah satu Negara China (Akbar et al., 2019).

\section{Cara Penanganan dan Pengolahan (Silaban, 2019).}

Penanganan awal untuk konsumsi dilakukan dengan cara membelah tubuh bagian tengah siasia (Sipunculus nudus) dengan menggunakan pisau untuk mengeluarkan semua organ dalam yang biasanya berisi pasir. Selanjutnya dicuci dan dibersihkan dengan air laut sebelum dimasukan ke dalam wadah dan siap dimasak untuk kepentingan pemenuhan protein dalam kehidupan sehari-hari. Bagian tubuh sia-sia (Sipunculus nudus) yang diambil untuk konsumsi hanya dagingnya saja, sementara seluruh isi perutnya dibuang. Daging sia-sia (Sipunculus nudus) yang sudah bersih kemudian dapat dikonsumsi dalam keadaan segar/mentah secara langsung atau kemudian diolah. Selain cara penangkapan yang membutuhkan teknik khusus, cara pengolahan sia-sia (Sipunculus nudus) juga memerlukan teknik khusus. Daging sia-sia (Sipunculus nudus) yang sudah bersih kemudian dicuci dengan air bersih sebanyak \pm 5 kali, kemudian direndam dalam air panas mendidih selama 20 menit. Setelah itu kulit luar dan dalam yang membungkusi tubuh dibersihkan dengan cara menarik bagian ujung pangkal tubuh sejajar kulit hingga bersih. Hal ini bertujuan untuk mengeluarkan butiran pasir yang melekat pada seluruh tubuhnya. Setelah bersih, daging sia-sia (Sipunculus nudus) kemudian dapat diolah menjadi berbagai olahan yang lezat.

\section{Pengolahan Kering (Akbar et al., 2019)}

Pengolahan cacing kacang yang dilakukan di industri rumah tangga di Desa Lemoea Kecamatan Kulisusu Kabupaten Buton Utara yaitu dengan cara diolah menjadi cacing kacang kering dari cacing kacang basah. Proses produksi atau pengolahan cacing kacang dapat dilihat pada diagram alir di mulai dari penerimaan dan pemilihan bahan baku, penimbangan, penusukan, pencucian, perebusan, pengovenan, pengeringan, dan hasil akhir berupa cacing kacang kering. Hasil penelitian menunjukkan bahwa bahan yang digunakan dalam proses pengolahan cacing kacang yaitu cacing kacang sebagai bahan baku utama dan minyak tanah, kayu bakar, dan arang sebagai bahan penunjang. Cacing kering yang telah di produksi dikemas dalam karung goni yang siap untuk didistribusikan pada permintaan pasar tujuan ekspor. 


\section{DAFTAR PUSTAKA}

Akbar L. M. D. I., La Karimuna, dan Herdhiansyah D., 2019. Analisis Nilai Tambah dan Agroindustri Cacing Kacang (Sipuncula sp.) di Desa Lemoea Kabupaten Buton Utara. Jurnal sains dan Teknologi Pangan. 4(4):2310-2322.

Aninda, G. R., Purwaningsih, S., dan Handharyani, E., 2016. Aktivitas Ekstrak Cacing Laut Siphonosoma australe Sebagai Antihiperglikemik pada Tikus Galur Sprague Dawley yang Diinduksi Streptozotocin. Skripsi. Bogor: Institut Pertanian Bogor.

Edmonds, S. J., 2000. Fauna of Australia Volume 4A Polychaetes \& Allies The Southern Synthesis. Australia : Commonwealth of Australia.

Fakhrurrozi Y., 2011. Studi etnobiologi, etnoteknologi dan pemanfaatan kekuak (Xenosiphon sp) oleh masyarakat di Kepulauan BangkaBelitung [skripsi]. Sekolah Pasca Sarjana. Institut Pertanian Bogor. Bogor.

Fakhrurrozi, Y., John, H., Ari, P., dan Soewarno, T. S., 2009. Tiga Jenis Alat Tangkap untuk Tujuan Komersial di Bangka. Jurnal Sumberdaya Perairan. 3(2):22-26

Gelatin Manufacturers Institue of America [GMIA]. 2019. Gelatin handbook. Canada : Weishardt International NA - TERGEL Inc. Leiwakabessy, J., Rico, R. R. M., dan Simon, P. O. L., 2017. Komposisi Kimia Cacing Kacang (Sipunculus nudus) di Kabupaten Raja Ampat dan Kabupaten Manokowari. Jurnal Sumberdaya Akuatik Indopasifik. 1(1):53-66.

Nurhikma, Tati N., dan Purwaningsih S., 2017. Kandungan Asam Amino, Asam Lemak dan Mineral Cacing Laut dari Sulawesi Tenggara. Jurnal Pengolahan Hasil Perikanan. 20(1):36-44.
Purwaningsih S. 2014. Pengembangan Pangan Fungsional Sebagai Antidiabetes dari Beberapa Moluska yang Mempunyai Aktivitas Antioksidan Tinggi [laporan akhir penelitian]. Bogor: Institut Pertanian Bogor. Rahayu, R., 2018. Analisis Kandungan Gizi Cacing Honingka (Siphonosoma australeaustrale) yang Berpotensi Sebagai Sumber Pangan Masyarakat Pesisir Sombu Kepulauan Wakatobi. Tesis. Jawa Timur : Universitas Muhammadiah Malang.

Silaban, B. br., 2012. Profil Nutrisi Sipuncula (Cacing Kacang); Biota Laut yang Kontrovertif di Pulau Nusalaut, Maluku Tengah, Ambon: Laporan Hasil Penelitian Dosen Pemula. Dibiayai dengan PNBP Lembaga Penelitian Universitas Patimura.

Silaban R., 2019. Studi Etnoteknologi dan Pemanfaatan Sia-Sia (Sipunculus Nudus) oleh Mayarakat di Pulau Nusalaut, Kabupaten Maluku Tengah. Jurnal Kelautan. 12(1):78-88.

Siregar, D.I.S. 2011. Kandungan gizi dan pemanfaatan gonad bulu babi (Echinothrix calamaris) yang terdapat di perairan Manokwari [skripsi]. Fakultas Peternakan, Perikanan dan IImu Kelautan. Universitas Negeri Papua. Manokwari.

Suwarjoyowirayatno, Sakir, Inthe M. G., Rhenislawaty, Fatimah S. A., 2019. Karakteristik fisiko-kimia gelatin dari sipou (Siphonosoma australe-australe) asal Sulawesi Tenggara. Jurnal Fish Protech 2(2):280-288.

Zhang, C. X., Zi R. D., and Qiu X. C.,2011. Anti-inflammatory and Anti-nociceptive Activities of Sipunculus nudus L. Extract. Journal of Ethnopharmacology. 137:11771182.

Zhang, C. X., and Zi R. D., 2011. Anti-hypoxia Activity of A Polysaccharide Extracted from The Sipunculus nudus L. International Journal of BiologicalMacromolecules. 49: 523-526 